\title{
Exploring Antecedents \& Consequences Of Customer Satisfaction With Smartphones: Implications For CRM
}

Kim, Arum, KDI School of Public Policy and Management, Korea

Cho, Yoon C., Ph.D., KDI School of Public Policy and Management, Korea

\begin{abstract}
Customers of smartphones spend most of their waking time using them, as they have become the most innovative electronic devices. As the time spent on smartphones increases, the customer's dependence on smartphones also increases. Therefore smartphones are more than telecommunication devices to customers. This paper examines factors (i.e., antecedents) affecting smartphone customer satisfaction and factors (i.e., consequences) arising from smartphone customer satisfaction. In particular, this study explores how the level of customer satisfaction affects loyalty, brand image, corporate image and country of origin. This study involved an online survey and applied t-test, factor, and regression analyses. The results provide managerial and theoretical implications for satisfaction and customer relationship management.
\end{abstract}

Keywords: Customer Satisfaction; Loyalty; Antecedents; Consequences; Smartphone

\section{INTRODUCTION}

Q ince its development from the telephone, customers have perceived the smartphone as a convenient product for interactive communication. Internet convergence technology has been integrated into the mobile phone, giving birth to an innovative electronic device called a smartphone, which has shown what ubiquitous really means. The Internet-based services available via smartphones have been rapidly and widely accepted by customers and the most sensational convergence of technology has dramatically transformed customers' lifestyles. As the smartphone market has grown, the number of smartphone customers has also significantly increased in a short period. By providing interactive and individualized services, the smartphone, as a customerdriven product, has changed attitudes and behavior. Based on this consideration, the purpose of this study is to investigate antecedents and consequences of customer satisfaction with smartphones. In particular, this study examines; i) what factors of smartphones influences customer satisfaction; ii) how customer satisfaction affects customer loyalty; and iii) how customer satisfaction affects brand image, corporate image, and country of origin.

\section{Literature Review}

The market for smartphones, known as convergent technological devices (Lee, Lee, \& Garrett, 2013) has been rapidly growing due to changing customer attitudes and behavior. Aksoy et al. (2012) stated that there has been a global explosion in the use of handheld electronic communication devices, such as mobile phones and other technological devices. Lee, Lee, and Garrett (2013) also mentioned that the convergent product is an increasingly important phenomenon in the marketplace. Liu (2010) suggested that smartphones help to manage everyday life by providing relevant information and strengthening users' relationships (Baglione, 2014). By adding functionalities, that provide opportunities for action afforded by a product (Gill \& Lei, 2009) and emotionality, firms consider they are improving customer satisfaction and loyalty.

Customer satisfaction has played a pivotal role in the theory of customer behavior. With the presence of the Internet and mobile phones, customer satisfaction and loyalty have played crucial roles in the importance of 
customer relationship management (CRM). The development of mobile commerce (m-commerce) as a medium has played an important role in everyday human life by setting up a hyper media environment (Hoffman \& Novak, 1996) that provides a higher level of interactive services. Customers' expectations of mobile phones have also increased. Customer satisfaction and loyalty have a considerable effect on profitability in competitive mobile environments as they have also been researched frequently in computer-mediated environments (Hoffman \& Novak, 1996). Previous studies have examined attitudinal and behavioral aspects, customer satisfaction, and loyalty toward mobile phones. Lee, Lee, and Feick (2001) investigated the impact of switching costs on the link between customer satisfaction and loyalty. Previous studies have also examined customers' perceptions and attitudes toward mobile Internet services (Lee, 2009), customer satisfaction and behavioral intentions towards mobile network service providers (Sakthivalrani \& Kannan, 2013), antecedents of customer loyalty (Kaur \& Soch, 2012), the dynamic effects of service recovery on customer satisfaction (Zheng, Xueming, \& Minghua, 2013), the effect of mobile advertising on customer attitudes and intentions (Bart, Stephen, \& Sarvary, 2014), the impact of product smartness on relative advantage, compatibility, observability and perceived risk (Rijsdijk \& Hultink, 2009), and consumer perceptions of the functionalities of a smartphone (Lee, Lee, \& Garrett, 2013).

Various scholars have developed the concept of customer satisfaction. Oliver (1997) defines satisfaction as fundamental to the well-being of individual consumers, to the profits of firms supported through purchasing and patronization, and to the stability of economic and political structures. Day (1977) viewed customer satisfaction as an outcome of consumers' evaluations of the products they experience. Oliver (1981) suggested that satisfaction is the summary psychological state resulting when the emotion surrounding disconfirmed expectations is coupled with the consumer's prior feelings about the consumption experience. Engel and Blackwell (1982) defined customer satisfaction as an evaluation that the chosen alternative is consistent with prior beliefs with respect to that alternative. Tse and Wilton (1988) also defined it as the consumer's response to the evaluation of the perceived discrepancy between prior expectations (or some other norm of performance) and the actual performance of the product as perceived after its consumption. According to Yi (1990), the satisfaction view of process more closely approaches the customer's unique measurement of satisfaction in a perceptual, evaluative and psychological way. Many researchers have adopted this approach (Day, 1984; Oliver, 1980). Sheth (1973), who viewed customer satisfaction as a customer-perceived status in which the customer sees the purchase as rewarding, stated that each customer has a different expectation due to his or her previous experience.

Oliver (1997) also addressed a behavioral perspective on the satisfaction of the consumer by applying a model of satisfaction that includes expectancy disconfirmation relationships, topics in consumer equity and fairness, and negative aspects of satisfaction (i.e., dissatisfaction and complaining behavior). The model of customer satisfaction proposed by Oliver (1997) includes the three stages of satisfaction, pre-satisfaction, and postsatisfaction. Factors of pre-satisfaction, known as antecedents, are generated based on expectancy, and the confirmation and disconfirmation paradigm, which also affects the evaluation of product performance (Yi, 1990), while factors of post-satisfaction are known as consequences generated based on concepts including regret, hindsight, equity, and interpretation of fairness (Oliver, 1997). Customer satisfaction has been also defined from two different perspectives. The first perspective defines customer satisfaction as an outcome, whereas the second perspective defines it as a process (Yi, 1990). From the outcome point of view, Howard and Sheth (1969) stated that satisfaction is defined as the buyer's cognitive state of being adequately or inadequately rewarded in a buying situation for the sacrifice he has undergone. Westbrook and Reilly (1983) supported the definition as an outcome by claiming that satisfaction is an emotional response to the experiences provided by, associated with particular products or services purchased, retail outlets, or even molar patterns of behavior such as shopping and buyer behavior, as well as the overall marketplace. As for the process definition, previous studies (Westbrook \& Reilly, 1983; Hunt, 1977) suggested that satisfaction is an evaluation that rendered that the (product ownership and usage) experience was at least as good as it was supposed to be.

\section{Theoretical Background}

Various scholars have generated a theoretical background that supports the concept of satisfaction. Cognitive dissonance theory, suggested by Festinger (1957), was the first attempt at a customer satisfaction study, and it provided an adequate framework for understanding the post-purchase responses (Oliver, 1981). Festinger (1957) claimed that the disconfirmed expectations cause a state of dissonance or psychological discomfort based on 
a psychological perspective. According to Yi (1989), the disparity between expectation and product performance forces customers to ease the psychological tension that is caused by the disparity. Westbrook (1980) defined satisfaction as a cognitive phenomenon, in which the customer feels subjectively good (satisfaction) or bad (dissatisfaction). Sherif and Hovland (1961) suggested an assimilation and contrast model based on the psychological framework, but it was very controversial and was not widely adopted due to conflicting test results (Cardozo, 1965; Woodside, 1972; Anderson, 1973). Contrast theory explained that when the product performance does not meet the customer's expectations, the difference between the expectation and the outcome affects customers, who tend to exaggerate the disparity (Engel \& Blackwell, 1982; Howard \& Sheth, 1969). According to contrast theory, if the disparity results from customers' perceptions of a difference between the expectation and the actual product performance, customers tend to evaluate the product rather than the expectation (Yi, 1990; Howard \& Sheth, 1969). Yi (1989) summarized that high expectations about product quality lead to more favorable ratings, whereas low expectations lead to less favorable ratings.

\section{Hypotheses Development}

This paper examines antecedents and consequences of customer satisfaction with smartphones. For antecedents of customer satisfaction, this study examines variables including quality, design, technology, price, country of origin, corporate image, and brand image. For consequences of customer satisfaction, this study investigates variables including loyalty, brand image, corporate image, and country of origin. Antecedents are based on perceptions of the smartphone's general performance, features and images, so that customers use those factors as informative cues for decision making. For both antecedents and consequences, this study considers variables such as brand image, corporate image, and country image. The proposed model suggests that the customer's evaluation ranges widely including loyalty, brand image, corporate image, and country image. In addition, it is posited that customer loyalty also influences the brand image, corporate image, and country of origin. By adapting Oliver's (1997) claim of the correlation between satisfaction and loyalty, this study posits that the loyalty formed by customer satisfaction and afterwards also has other consequences.

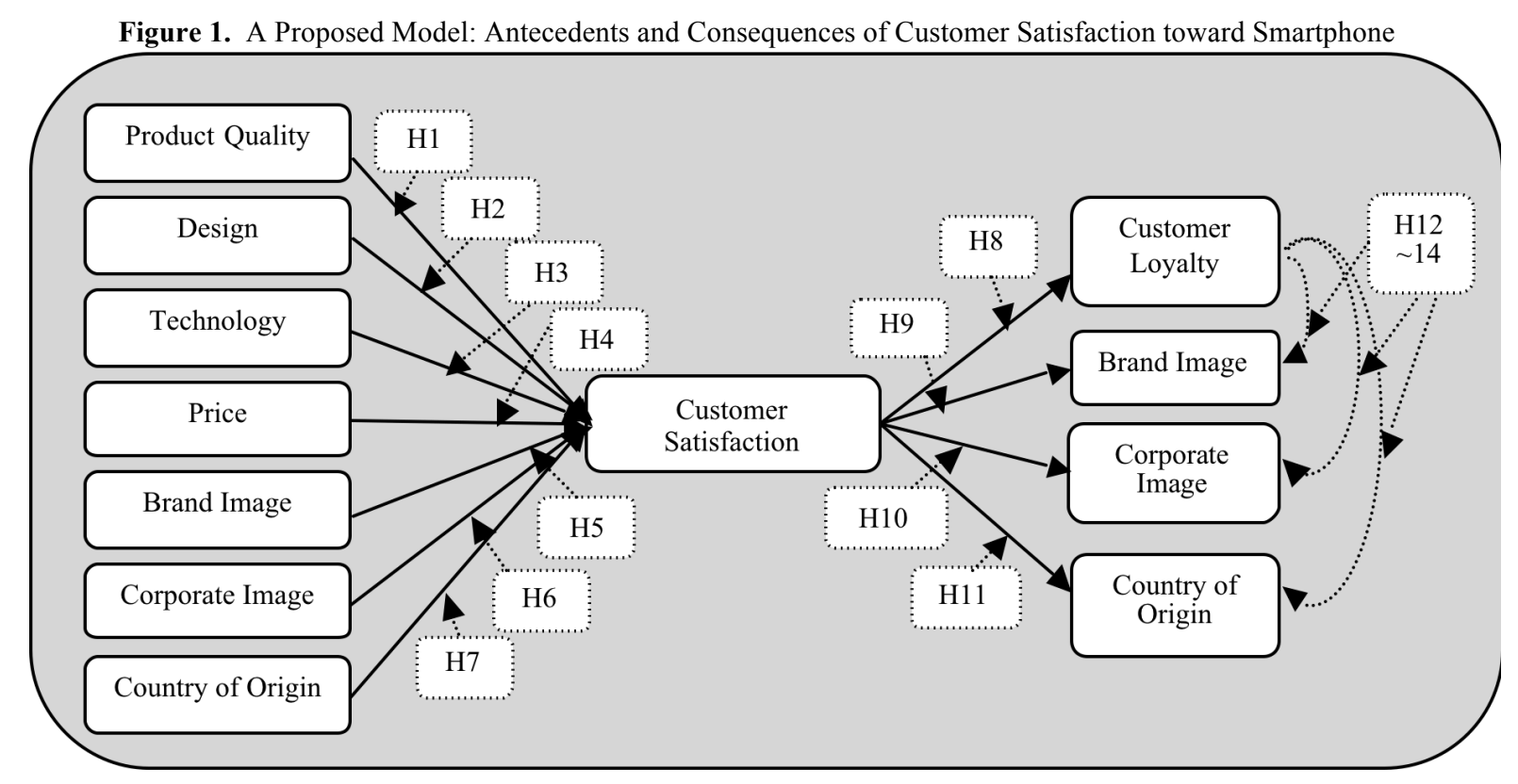




\section{Effects of Antecedents on Customer Satisfaction}

\section{Effects of Product Quality on Customer Satisfaction}

Product quality provides crucial information for customers when purchasing products, and this information is also used as a significant weapon for business organizations to capture customers. Previous studies stated that quality is the key factor contributing to delighted customers, firm profitability, and the economic growth of nations (Peter, Mitra, \& Moorman, 2012; Deming, 1982; Rust, Zahorik, \& Keiningham, 1995). Many researchers have examined the importance of customers' perceptions of quality has been examined by many researchers. (Buzzell \& Gale, 1987; Parasuraman, Berry, \& Zeithaml, 1991). Zeithaml (1988) claimed that perceived quality is the customer's overall evaluation of the product's superiority or excellence. According to Golder, Mitra and Moorman (2012), the quality evaluation process occurs when customers compare an offering's perceived attributes with their expectations to form summary judgments of quality and then satisfaction. Oliver (1980) inferred that customer satisfaction increases as product quality is improved, and that customer satisfaction influences customer loyalty. As the most substantial factor, the quality of smartphones plays an important role in customers' perception and evaluation of the smartphone satisfaction. Therefore, it is hypothesized that product quality significantly affects customer satisfaction with the smartphone.

H1: Perception of better product quality has a positive effect on customer satisfaction.

\section{Effects of Design on Customer Satisfaction}

The design of the product is one of the most important factors customers use to decide their attitudes toward products. Design is defined as a creative activity whose aim is to establish the multi-faceted qualities of objects, processes, services and their systems in whole life cycles (http://www.icsid.org). Bilkey and Nes (1982) have seen a design as one of the information cues of a product, especially an intrinsic cue, and have seen that customers are using that cue for product evaluation. Best (2006) suggested that design can add value to a product beyond the manufacturing process, and so can affect gross margin, performance and profitability. Design has been considered as an important factor to attract customer attention and provide convenience in the smartphone market. The relationship of product design and customer satisfaction has been researched in previous studies. Jawwad et al. (2013) explored the effects of integrated product design on customer satisfaction. Based on this consideration, this study hypothesized that design factors significantly affect customer satisfaction with the smartphone.

H2: Perception of better design has a positive effect on customer satisfaction.

\section{Effects of Technology}

Technology is a driving force of product evolution. Technology acceptance has been widely applied in the online environment. By proposing the technology acceptance model, Davis (1989) addressed the process of users' acceptance of technology in terms of perceived usefulness and perceived ease of use. Earlier studies of e-commerce considered how customers adopt technology in a computer-mediated environment (Sagynov \& Cho, 2015). The effects of technology acceptance on customer satisfaction in e-commerce have been frequently studied (e.g., Wong, Lo, and Ramayah 2014). Cho and Agrusa (2007) applied approaches to customer satisfaction measurement with the consideration of technology acceptance. How customers perceive technology has also greatly influenced customers' attitudes and behavior in the mobile phone environment. By adding improved technology, smartphone customers' expectations will be increased. It is hypothesized that the perceived technology significantly affects customer satisfaction with the smartphone.

H3: Perception of better technology has a positive effect on customer satisfaction.

\section{Effects of Price on Customer Satisfaction}

Price has played a pivotal role in customer response and decision making. Perceived price is the initial information on which a customer makes a purchase intention. Jung, Cho, and Lee (2014) stated that a buyer's 
perception of price is a consequence of individual cognition and perception. It is possibly expected that the customer has a high level of price tolerance when the product gives greater satisfaction (Anderson, 1996). Marshall (1920) claimed that the excess of the price a customer would be willing to pay rather than go without having a thing over what the customer actually does pay is the economic measure of his or her satisfaction surplus (Anderson, 1996). When customers evaluate the purchased smartphone, the price determines the expectation level of the smartphone. Price information, stored in a consumer's memory serves as a point of comparison for future purchases (Han, Gupta, \& Lehmann, 2001). It is hypothesized that the perceived price significantly affects customer satisfaction with the smartphone.

H4: Perception of low price has a positive effect on customer satisfaction.

\section{Effects of Brand Image on Smartphone Satisfaction}

Various studies have examined the concept of image. Boulding (1956) said that image is the objective knowledge that is categorized and manipulated into the useful unit of perception based on the received information. Scott (1966) stated that an image is comprised of an individual's understanding of the object (Lamelas, 2011). It is the cognitive component, the affective assessment of the object, and finally, the responses to the object that make up the behavioral component (Lamelas, 2011). Moffitt (1994) said that images are produced by organizational, social, and personal relations, texts, and personal experiences. Images result from a complex process that may yield multiple, intended and unintended, positive and negative, and strong and weak meanings (Moffitt, 1994). People's attitudes and actions toward an object are highly conditioned by that object's image (Kotler, 1994). Among different types of images, brand image is used as one information cue for customers. Various studies examined the concept related to the brand. Aaker $(1991,1996)$ discussed the dimensions of brand awareness, brand associations, customer satisfaction based brand loyalty, and brand equity. Brand image, as part of brand dimension, has been regarded as one of the variables that affect customer satisfaction. Tsai and Yeh (2012) examined relationships among brand image, customer satisfaction, and loyalty for the digital camera. Srivastava and Sharma (2013) investigated relationships of corporate brand image on switching behavior via customer satisfaction for the telecommunications industry. It is hypothesized that perception of brand image significantly affects customer satisfaction with the smartphone.

H5: Perception of a positive brand image has a positive effect on customer satisfaction.

\section{Effects of Corporate Image on Smartphone Satisfaction}

Corporate image influences customers' decisions to buy the smartphone behind the product. The corporate image and its influence are hard to define, but customers consider the corporate image as a way to evaluate the smartphone. According to Boulding (1956), a strong and favorable corporate image generally influences customers' attitudes and behavior towards the company. Previous studies also examined the relationship between corporate image and customer satisfaction (Srivastava and Sharma 2013). This study hypothesized that perception on corporate image significantly affects customer satisfaction toward the smartphone.

H6: Perception of a better corporate image has a positive effect on customer satisfaction.

\section{Effects of Country of Origin on Customer Satisfaction}

County of origin effects on customers' evaluations of product have been of interest to researchers since the 1060s (Schooler, 1965, cited in Schaefer 1997). Dichter (1962) provided a starting point for the country-of-origin research by examining the differential role of national pride, which affects the product in terms of international marketing. Dichter (1962) saw the country of origin as a symbol of the producing country of the product and concluded that the made-in label has a tremendous influence on the acceptance and success of the product. Schooler (1965) first conducted an empirical test on the "made in" label of the product and proved the significant influence of country of origin. Bilkey and Nes (1982) questioned the perspective of seeing the country image as a single cue for consumers to judge the quality of the product, while subsequent researchers began to use the term multi-cue to measure the effect of country of origin. Chao (1993) pointed out the misuse of the term country of origin in the 
context of the companies' strategies for dispersing factories into other countries by proposing other terms, such as made-in, designed-in or engineered-in. Obermiller and Spangenberg (1989) claimed that the perception of country of origin directly affects brand evaluations or customer's attitudes. It is hypothesized that perception of country of origin significantly affects customer satisfaction with the smartphone.

H7: Perception of superior country of origin has a positive effect on customer satisfaction.

\section{Consequences of Customer Satisfaction}

\section{Effects of Customer Satisfaction on Loyalty}

Customer loyalty is regarded as a proxy for customer satisfaction. Customer loyalty has been generally known as a factor that is directly influenced by customer satisfaction (Mittal and Lassar, 1998; Oliver, 1997). Customer loyalty is considered as an important state in the customer's post-purchase behavior, because loyalty influences the customer's re-purchase (Oliver, 1999). Bowen and Chen (2001) mentioned that having satisfied customers is not enough, and that extremely satisfied customers are needed. Sivadas and Baker-Prewitt (2000) stated that there is an increase in recognition of customer loyalty that should be a measurement of customer satisfaction. Dick and Basu (1994) mentioned that customer satisfaction is the key determinant of customer loyalty. Heskett et al. (1994) stated that when customer satisfaction rises over a certain threshold, customer loyalty increases rapidly. Aaker (2006) also claimed that measurement of customer satisfaction must be done before purchase in order to measure customer loyalty based on the correlation between satisfaction and loyalty. Jones and Sasser (1995) mentioned that merely satisfying customers who have the freedom to make choices is not enough to keep them loyal. While there are arguments that even highly satisfied customers may not become loyal (Reichheld, 1994), it is hypothesized that the level of satisfaction significantly affects customer loyalty toward the smartphone.

H8: A higher level of customer satisfaction has a positive effect on loyalty.

\section{Effects of Customer Satisfaction on Brand Image}

Kotler (1994) inferred that image is the set of beliefs, ideas, and impressions that a person holds regarding an object. Brand image is defined as a name, term, sign, symbol, or design, or a combination of them, intended to identify the goods or services of one seller or group of sellers and to differentiate them from those of competitors (Lamelas, 2011; Kotler, 1994). Brand image is also the key to building blocks in customer-related brand equity frameworks (Aaker, 2006; Keller, 1993). Biel (1993) stated that the brand image is considered a common tool in order to sell a single brand in various cultures. Earlier, the effects of brand image on customer satisfaction were hypothesized. It is also hypothesized that the level of satisfaction significantly affects the brand image of the smartphone.

H9: A higher level of customer satisfaction has a positive effect on brand image.

\section{Effects of Customer Satisfaction on Corporate Image}

Corporate image is defined as the way corporations believe others see the organization (Dutton \& Dukerich, 1991). Corporate image is also defined as a corporate identity, which does not come from a company's logo, name, or other graphic elements, but from a company's overall definition, direction, and distinctiveness as perceived by its various customers (Moffitt, 1994). Barich and Kotler (1991) described corporate image as the overall impression made on the minds of the public about an organization. Previous studies examined cognitive and affective components that constitute the corporate image constructs (Bernstein, 1984; Dowling, 2001) and perceptions or impressions of an organization that reside in the public mind (Gronroos, 1984; Gray \& Balmer, 1998). Srivastava and Sharma (2013) examined the effects of corporate image (e.g., reputation and credibility) on satisfaction. Abd-El-Salam, Shawky, and El-Nah (2013) explored the relationship of corporate image and customer satisfaction for a service company. Based on this consideration, this study hypothesized that the level of satisfaction also significantly affects corporate image of the smartphone. 
H10: A higher level of customer satisfaction has a positive effect on corporate image.

\section{Effects of Customer Satisfaction on Country of Origin}

Many researchers have tried to examine how the country of origin affects the customer's choice of product. Etzel and Walker (1974) investigated the effects of country of origin with attitudes toward specific products. Schaefer (1997) investigated effects of dimensions of customer knowledge on country of origin in evaluating products. Country of origin is also regarded as part of country image that can be classified into the following: i) the image of a country (Martin \& Eroglu, 1993; Kotler, 1994), ii) a product-country of origin indicating the producing country (Roth \& Romeo, 1992), and iii) a product image including the country image as the country of origin and associated with mass communication, personal experience, and views of national opinion leaders (Nagashima, 1970). This study posited that customers consider country of origin before making purchase decisions, while they form an overall image of the country in after purchase decisions based on level of satisfaction. Therefore, in the case of dissatisfaction, customers' perceptions of country of origin, will be decreased. Based on this consideration, this study hypothesized that the level of satisfaction significantly affects the country image of the smartphone.

H11: A higher level of customer satisfaction has a positive effect on country image.

\section{Effects of Loyalty on Corporate and Country of Origin}

It is posited that loyalty also has other consequences as the independent variable. Oliver (1999) stated that loyalty can be classified on the same level as customers' assessments following customer satisfaction. It is hypothesized that loyalty influences perceived brand, corporate, and country of origin.

H12: A higher level of customer loyalty has a positive effect on brand image.

H13: A higher level of customer loyalty has a positive effect on corporate image.

H14: A higher level of customer loyalty has a positive effect on country of origin.

\section{METHODOLOGY}

\section{Data Collection}

This study used an online survey hosted by qualitrics.com for smartphone users. A URL link was sent out via e-mail addresses obtained from organizations. Screening questions asked subjects about their experience of smartphone usage and their perceptions about smartphone. Cookie tracking and control ensured that each subject filled out the survey only once.

\section{Development of Research Questionnaire}

The questionnaire was structured based on the proposed model, and asked about the customer's perceptions of certain variables. The survey questions used a 5-point Likert scale. As a first step, participants were asked how important they think certain factors are when choosing a smartphone. The survey also included questions regarding the evaluation of importance of variables. For valuation questions a Likert scale was used in which 1 meant very bad, while 5 meant very good. For the other questions, a 5-point Likert scale ranging from 1 (strongly disagree) to 5 (strongly agree) was used. This study measured brand image separately from corporate image. This study proposed that customers form different degree of perception for the smartphone's brand and corporate image. Each item has been selected and modified from previous studies (e.g., Anderson, 1996; Anderson and Sullivan, 1993; Bowen and Chen, 2001) Keywords used for the measurement of brand image include brand preference, brand credibility, brand familiarity, and brand awareness, while for the measurement of corporate image the keywords include corporate international reputation, financial stability, management policy and style. 


\section{DATA ANALYSIS}

\section{Response Rate and Data Validity}

For this research, the survey questionnaire was distributed to 2,000 people. A total of 369 respondents answered questionnaires. Of these 369 respondents, 317 respondents used smartphones, while 52 respondents did not. The 52 who answered that they had no smartphone were accordingly excluded from the data analysis. In addition, 51 incompletely answered questionnaires were also excluded. Consequently, 266 responses were used for the data analysis, with a response rate of $6 \%$.

\section{Demographics}

Among the respondents, $66 \%$ of respondents were male and $34 \%$ were female. $17 \%$ were between 25 and $29,34 \%$ were between 30 and $34,17 \%$ were between 35 and $39,14 \%$ were in the age group of between 40 and 44 , $11 \%$ were between 45 and 49 , and $7 \%$ were above $50.53 \%$ of respondents hold a master's degree, and $34 \%$ of respondents have completed a bachelor's degree. University students accounted for $7 \%$ of the sample, and others made up $6 \%$. Moreover, $47 \%$ were office workers, and $18 \%$ had specialized jobs. Regarding annual income, the respondents were distributed uniformly from zero to over $\$ 70,000.20 \%$ of respondents had an annual income over $\$ 70,000$, which accounts for a large portion of the sample.

\section{Usage of Smartphone Brands}

The respondents were divided into three large groups according to smartphone company. The largest group of participants used Samsung phones, accounting for $43 \%$, and the second largest group was Apple users, accounting for $36 \%$. The third group was others, including each of six companies, LG (5\%), Sony Ericson (2\%), NOKIA (3\%), RIM (4\%), Motorola (1\%) and HTC (1\%). Other suppliers accounted for less than 5\%.

\section{Hypothesis Testing Results}

Reliability Test

A reliability test was conducted by applying Cronbach's alpha. The results of Cronbach's alpha for antecedents of customer satisfaction were 0.84 for product quality, 0.76 for design, 0.79 for technology, 0.73 for price, 0.91 for brand image, 0.81 for corporate image, and 0.84 for country-of-origin. Cronbach's alpha for customer satisfaction was 0.90 . The results of Cronbach's alpha for consequences of customer satisfaction was 0.94 for loyalty, 0.96 for brand name, 0.96 for corporate image, and 0.88 for country of origin.

\section{Factor Analysis}

This study conducted a confirmatory factor analysis to check validity. Using principal components analyses as the extraction method and Varimax rotation methods with Kaiser Normalization, the most relevant data emerged among those specified factors (Sagynov and Cho 2015). These analyses showed distinct reduced factors, with Eigen values over 1.00. As a result, the reduced factors emerged strongly as factors with high relevance (Tables 1 and 2). 
Table 1. Component Matrix: Antecedent Factors of Customer Satisfaction toward Smartphone

\begin{tabular}{|c|c|c|c|c|c|c|c|c|}
\hline \multicolumn{2}{|r|}{ Items } & \multicolumn{7}{|c|}{ Component } \\
\hline External Factors & List of Keywords for Scale Items & 1 & 2 & 3 & 4 & 5 & 6 & 7 \\
\hline QUALITY 1 & Picture quality & .827 & & & & & & \\
\hline QUALITY 2 & Sound quality & .809 & & & & & & \\
\hline QUALITY 4 & Camera function & .786 & & & & & & \\
\hline QUALITY 3 & Call quality & .752 & & & & & & \\
\hline DESIGN 2 & Weight & & .816 & & & & & \\
\hline DESIGN 1 & Color & & .792 & & & & & \\
\hline DESIGN4 & Size & & .781 & & & & & \\
\hline DESIGN 3 & User interface & & .654 & & & & & \\
\hline TECHNOLOGY 1 & Installed basic technology & & & .869 & & & & \\
\hline TECHNOLOGY 3 & Data management technology & & & .832 & & & & \\
\hline TECHNOLOGY 2 & Voice recognition technology & & & .825 & & & & \\
\hline PRICE 3 & Perception on price & & & & .847 & & & \\
\hline PRICE1 & Price compared with product performance & & & & .839 & & & \\
\hline PRICE4 & Optional product price & & & & & & & \\
\hline BRAND IMAGE 2 & Brand Preference & & & & .731 & .915 & & \\
\hline BRAND IMAGE 1 & Brand Credibility & & & & & .892 & & \\
\hline BRAND IMAGE 3 & Brand Familiarity & & & & & .875 & & \\
\hline BRAND IMAGE 4 & Brand Awareness & & & & & .864 & & \\
\hline CORPORATE IMAGE 2 & Corporate international reputation & & & & & & .875 & \\
\hline CORPORATE IMAGE 3 & Corporate financial stability & & & & & & .818 & \\
\hline CORPORATE IMAGE 1 & Corporate management policy/style & & & & & & .786 & \\
\hline COUNTRY-OF-ORIGIN 1 & Global reputation of Country-of-origin & & & & & & & .905 \\
\hline COUNTRY-OF-ORIGIN 2 & Level of economic development & & & & & & & .863 \\
\hline COUNTRY-OF-ORIGIN 4 & Technical skill of Country-of-origin & & & & & & & .844 \\
\hline
\end{tabular}


Table 2. Component Matrix: Consequent Factors of Customer Satisfaction toward Smartphone

\begin{tabular}{|c|c|c|c|c|c|}
\hline \multicolumn{3}{|c|}{ Items } & \multicolumn{3}{|c|}{ Component } \\
\hline External Factors & Scale Items & 1 & 2 & 3 & 4 \\
\hline LOYALTY 1 & I have attachments to my smart phone brand. & .927 & & & \\
\hline LOYALTY 3 & I will consistently purchase smart phone of the same brand. & .916 & & & \\
\hline LOYALTY 4 & I will repurchase same smart phone. & .904 & & & \\
\hline LOYALTY 2 & I have attachments to my smart phone. & .869 & & & \\
\hline BRAND IMAGE 2 & I have more preference to my smart phone brand. & & .941 & & \\
\hline BRAND IMAGE 1 & $\begin{array}{l}\text { Overall the brand image of my smart phone is positively } \\
\text { improved. }\end{array}$ & & .927 & & \\
\hline BRAND IMAGE 4 & I have more familiarity to my smart phone company. & & .910 & & \\
\hline CORPORATE IMAGE 2 & I trust more my smart phone company. & & & .947 & \\
\hline CORPORATE IMAGE 5 & I have more preference to my smart phone company. & & & .941 & \\
\hline CORPORATE IMAGE 1 & $\begin{array}{l}\text { Overall the company image of my smart phone is positively } \\
\text { improved. }\end{array}$ & & & .927 & \\
\hline CORPORATE IMAGE 3 & I have more familiarity to my smart phone company. & & & .917 & \\
\hline COUNTRY OF ORIGIN 3 & $\begin{array}{l}\text { I think that the country of my smart phone company has a } \\
\text { good international reputation }\end{array}$ & & & & .909 \\
\hline COUNTRY OF ORIGIN 1 & $\begin{array}{l}\text { I think that the country of my smart phone company has many } \\
\text { globalized technologies. }\end{array}$ & & & & .888 \\
\hline COUNTRY OF ORIGIN 2 & $\begin{array}{l}\text { Overall the country image of my smart phone company is } \\
\text { positively improved. }\end{array}$ & & & & .739 \\
\hline
\end{tabular}

Test of Hypotheses

Table 3 shows the results of the multiple regression analysis for antecedents with customer satisfaction. This study used factor scores for regression analysis. The effects of antecedents on customer satisfaction with smartphones indicated that the model was significant at the $\alpha=0.01$ level, with $r$-square $=.443$. The result of the ANOVA was also significant at the $\alpha=0.01$ level, with $F=26.553$. As shown in Table 3, antecedents excluding corporate image and country of origin were significant. Therefore, hypotheses 1, 2, 3, 4, and 5 were accepted while hypotheses 6 and 7 were rejected. The results also showed that the effect of brand image on customer satisfaction was the largest value.

Table 3. Summary of the Effects of Antecedents on Customer Satisfaction.

\begin{tabular}{lc}
\hline \multicolumn{1}{c}{ Variable (Independent -> Dependent) } & Standardized Coefficient (t-value-Sig) \\
\hline Product Quality -> Customer Satisfaction (H1) & $0.140\left(2.585^{* * *}\right)$ \\
Design -> Customer Satisfaction (H2) & $0.132\left(2.174^{* *}\right)$ \\
Technology -> Customer Satisfaction (H3) & $0.175\left(2.689^{* * *}\right)$ \\
Perceived Price -> Customer Satisfaction (H4) & $0.186\left(3.161^{* * *}\right)$ \\
Brand Image -> Customer Satisfaction (H5) & $0.416\left(6.153^{* * *}\right)$ \\
Corporate Image -> Customer Satisfaction (H6) & $-0.103(-1.405)$ \\
Country-of-origin -> Customer Satisfaction (H7) & $0.006(0.094)$ \\
\hline
\end{tabular}

*** Significant at 0.01 level (2-tailed)

Table 4 shows the results of the regression analyses for consequences with customer satisfaction. This study also used factor scores for regression analyses. The effects of customer satisfaction on loyalty indicated that the model was significant at the $\alpha=0.01$ level, with $r$-square $=.520$. The result of the ANOVA was also significant at the $\alpha=0.01$ level, with $F=276.193$. The effects of customer satisfaction on brand image indicated that the model was significant at the $\alpha=0.01$ level, with $r$-square $=.490$. The result of the ANOVA was also significant at the $\alpha=$ 0.01 level, with $F=244.491$. The effects of customer satisfaction on corporate image were significant at the $\alpha=$ 0.01 level, with $r$-square $=.394$. The result of the ANOVA was also significant at the $\alpha=0.01$ level, with $F=$ 167.282. The effects of customer satisfaction on country of origin showed that the model was significant at the $\alpha=$ 0.01 level, with $r$-square $=.083$. The result of the ANOVA was also significant at the $\alpha=0.01$ level, with $F=$ 
23.214. As shown in Table 4, this study found that effects of customer satisfaction on consequences were significant. The consequences including loyalty, brand image, corporate image and country of origin, are influenced by customer satisfaction. Therefore, hypotheses $8,9,10$, and 11 were all accepted.

Table 4. Summary of the Effects of Consequences on Customer Satisfaction.

\begin{tabular}{lc}
\hline \multicolumn{1}{c}{ Variable (Independent -> Dependent) } & Standardized Coefficient (t-value-Sig) \\
\hline Customer Satisfaction -> Loyalty (H8) & $0.721\left(16.619^{* * *}\right)$ \\
Customer Satisfaction -> Brand Image (H9) & $0.700\left(15.636^{* * *}\right)$ \\
Customer Satisfaction -> Corporate Image (H10) & $0.628\left(12.934^{* * *}\right)$ \\
Customer Satisfaction -> Country of origin (H11) & $0.288\left(4.818^{* * *}\right)$ \\
\hline
\end{tabular}

*** Significant at 0.01 level (2-tailed)

Table 5 shows the results of the regression analyses for effects of loyalty on brand, corporate, and country of origin. The effects of loyalty on brand image indicated that the model was significant at the $\alpha=0.01$ level, with $r$-square $=.758$. The result of the ANOVA was also significant at the $\alpha=0.01$ level, with $F=783.026$. The effects of loyalty on corporate image indicated that the model was significant at the $\alpha=0.01$ level, with $r$-square $=.641$. The result of ANOVA showed also significant at the $\alpha=0.01$ level, with $F=452.378$. The effects of loyalty on country of origin indicated that the model was significant at the $\alpha=0.01$ level, with $r$-square $=.170$. The result of the ANOVA was also significant at the $\alpha=0.01$ level, with $F=51.391$. As shown in Table 5, the effects of loyalty on brand, corporate image, and country of origin were significant. Therefore, hypotheses 12,13 , and 14 were all accepted.

Table 5. Summary of the Effects of Loyalty on Brand, Corporate, and Country of Origin

\begin{tabular}{|c|c|}
\hline Variable (Independent -> Dependent) & Standardized Coefficient ( $t$-value-Sig) \\
\hline Loyalty -> Brand Image (H12) & $0.871(27.983 * * *)$ \\
\hline Loyalty -> Corporate Image (H13) & $0.801\left(21.269^{* * *}\right)$ \\
\hline Loyalty -> Country of Origin (H14) & $0.412\left(7.169^{* * *}\right)$ \\
\hline
\end{tabular}

*** Significant at 0.01 level (2-tailed)

\section{CONCLUSION}

The study first proved hypotheses about the effects of antecedents on customer satisfaction with smartphones. By applying the model of customer satisfaction (Oliver 1980), this study proposed antecedents and consequences of customer satisfaction. Effects of antecedents and consequences on customer satisfaction are considered as fundamental for relationship marketing. Antecedents to satisfaction proposed in this study included the product quality, design, technology, price, brand image, corporate image, and country of origin. Further, this study also proved effects of satisfaction on consequences including loyalty, brand image, corporate image, and country of origin. This study also examined the effects of loyalty on other consequences, such as brand image, corporate image, and country of origin. The findings of the study indicate positive relationships between most of the antecedents excluding corporate image and country of origin, and satisfaction and satisfaction with consequences.

Based on the results, this study provides implications both theoretically and managerially. First, theoretically, this study applied the model of customer satisfaction in m-commerce environments particularly for perceptions of the smartphone. This study extends the relationships of customer satisfaction with smartphones by examining antecedents and consequences that are significant for customer relationship marketing. In particular, this study examined the effects of customer satisfaction on consequences that have been less investigated by prior studies, such as corporate image and country of origin. Previous studies often considered corporate image and country of origin as antecedents, while the effects of those as consequences of satisfaction are less examined. The results showed that antecedents of both corporate image and country of origin do not significantly affect to customer satisfaction while customer satisfaction affects consequences of both corporate image and country of origin showed significant. In addition, this study also examined the effects of relationships of loyalty on other consequences in the case of smartphones. The model of customer satisfaction (Oliver, 1980) stated that loyalty is the last stage among 
relationships of satisfaction. By proving the effects of loyalty on consequences such as brand and corporate image, and country of origin, this study implies the importance of those effects that are affected by loyalty.

Concerning the managerial implication, this study examined what factors affect customer satisfaction and how satisfaction affects consequences when customers make purchase decisions. In particular, this study found that customer satisfaction and loyalty significantly affect country of origin. Proposed factors that affect satisfaction and satisfaction with the post-purchase decision provide managerial implications for the purchase decision of a product and implications for customer relationship management (CRM). This study examined different types of images including brand and corporate image. How customers perceive brand is considered separately from how customers perceive corporate image in this study. As the study results show, the effects of brand image on customer satisfaction is significant, while the effects of corporate image on customer satisfaction was not significant. In other words, perception of brand image affects customer satisfaction, while perception of corporate image does not affect customer satisfaction. The results imply that perceptions of brand and corporate image differ and are regarded as separate variables to measure satisfaction. The smartphone business should consider different strategies for the development of brand and corporate images. In addition, how loyalty affects country of origin should be considered to be an important strategic issue. All variables investigated in relationships among antecedents and consequences of customer satisfaction need to be applied for strategies of smart phone businesses' customer relationship management.

This study has limitations. This study did not measure cause-and-effect relationships by using software such as LISREL. The results of the study could be improved by increasing the sample size to increase generalizability. Future study should consider increased response rate by applying diverse methodology. Further studies could also consider other environments for generalization. This study also does not consider the equal number of respondents for each smartphone brand. Further studies might conduct a comparison analysis by measuring perceptions of specific brands.

\section{REFERENCES}

Aaker, D. A. (2001), Managing Brand Equity, New York: Free Press.

Aaker, D. A. (2006), "Measuring Brand Equity across Products and Markets," California Management Review, 38, Spring, 102-120.

Abd-El-Salam, E., Shawky, A., El-Nah, T. (2013)," The impact of Corporate image and Reputation on Service Quality, Customer Satisfaction, and Customer Loyalty: Testing the Mediating role. Case Analysis in an International Service Company," Journal of Business \& Retail Management Research, 8(1), 130-153.

Aksoy, Lerzan, Alexander Byoye, Pelin Aksoy, Bart Lariviere, and Timothy L. Keiningham (2012), "A CrossNational Investigation of the Satisfaction and Loyalty Linkage for Mobile Telecommunications Services across Eight Countries," Journal of Interactive Marketing, 11 (November), 74-82.

Anderson, E.W. (1996), "Customer satisfaction and price tolerance," Marketing Letters, 7(3), 265-274.

Anderson, E.W., and Sullivan, M.W. (1993), "The Antecedents and Consequences of Customer Satisfaction for Firms," Marketing Science, 12(2), 125-143.

Anderson, Rolph E. (1973), "Consumer Dissatisfaction: The Effects of Disconfirmed Expectancy on Perceived Product Performance," Journal of Marketing Research, 10 (February), 38-44.

Baglione, Stephen L. (2014), “Are Smartphone A Smart Marketing Buy?” International Journal of Business, Marketing, and Decision Sciences, 7(1), Summer, 19-31.

Bart, Yakov, Stephen, Andrew T., and Sarvary, Miklos (2014), "Which Products are Best Suited to Mobile Advertising? A Field Study of Mobile Display Adver4tising Effects on Consumer Attitudes and Intentions," Journal of Marketing Research, 51(3), 270-285.

Bernstein, D. Company Image and Reality (1984), A Critique of Corporate Communications, Holt, Rinehart \& Winston, Eastbourne.

Best, Kathryn (2006), Design Management: Managing Design Strategy, Process and Implementation, Lausanne, AVA Publishing SA.

Biel, A. (1993), Converting image into equity in brand equity and advertising, D. A. Aaker and A Biel(Dds). Hillsdale, NJ: Lawrence Erlbaum Associates. 
Bilkey, W. J. and Nes, Eric (1982), “Country-of-Origin Effects on Product Evaluations,” Journal of international Business Studies, 13(1), 89-99.

Boulding, K. E. (1956), The Image: Knowledge in Life and Society, Ann Arbor. Michigan: The University of Michigan Press.

Bowen, J. T. and Chen, S. L. (2001), “The Relationship between Customer Loyalty and Customer Satisfaction,” International Journal of Contemporary Hospitality Management, 13(5), 213-217.

Buzzell, Robert D. and Gale, Bradley T. (1987), The PIMS principles: linking Strategy to Performance, New York: The Free Press.

Cardozo, Richard N. (1965), “An Experimental Study of Consumer Effort, Expectation, and Satisfaction,” Journal of Marketing Research, 2 (August), 244-249.

Chao, P. (1993), "Partitioning country of origin effects: Consumer evaluations of a hybrid product," Journal of International Business studies. 24(2), 291-306.

Cho, Y. and Agrusa, J. (2007), "How the Media is a Significant Promotional Tool to Deliver Marketing Messages to Audiences?" International Business \& Economics Research Journal (IBER), 6(10). 61-74.

Davis, F. D. (1989), "Perceived Usefulness, Perceived Ease of Use, and User Acceptance of Information Technology," MIS Quarterly, September, 13(3), 319-340.

Day, Ralph L. (1977), "Modeling Choices Among Alternative Responses to Dissatisfaction," Advances in Consumer Research. T. Kinnear, ed. Ann Arbor, MI: Association for Consumer Research.

Day, Ralph L. (1984), "Modeling Choices among Alternative Responses to Dissatisfaction," Advances in Consumer Research. T. Kinnear, ed. Ann Arbor, MI: Association for Consumer Research.

Deming, W. Edwards (1982), Quality, Productivity, and Competitive Position, Cambridge, MA: MIT Press.

Dichter, E. (1962), “The World Customer," Harvard Business Review, 40 (April), 113-122.

Dick, A. S. and Basu, K. (1994), "Customer loyalty: Toward an Integrated Conceptual Framework," Journal of the Academy of Marketing Science. 22(2), 99-113.

Dowling, G. R. (2001), Creating Corporate Reputations. Identity, Image and Performance, Oxford, University Press, Oxford.

Dutton, J. E. and Dukerich, J. M. (1991), "Keeping an Eye on the Mirror: Image and Identity in Organizational Adaptation," Academy of Management Journal, 34(3), 517-54.

Engel, James F. and Blackwell, Roger D. (1982), Consumer Behavior, New York: Holt, Rinehard and Winston. Festinger, Leon (1957), A Theory of Cognitive Dissonance, Stanford, California, Stanford University Press.

Gill, Tripat and Lei, Jing (2009), "Convergence in the High-Technology Consumer Markets: Not All Brands Gain Equally from Adding New Functionalities to Products," Marketing Letters, 20, 91-103.

Golder, P. N., Mitra, D., and Moorman, C. (2012), "What is quality? An Integrative Framework of Processes and States," Journal of Marketing, 76, July, 1-23.

Gray, E. R. and Balmer, J. M. T. (1998), "Managing Corporate Image and Corporate Reputation," Long Range Planning, 31(5), 695-702.

Gronroos, C. (1984), “A service quality model and its marketing implications,” European Journal of Marketing, $18(4), 36-44$.

Han, S. M., Gupta, S., and Lehmann, D. R. (2001). Consumer Price Sensitivity and Price Threshold, Journal of Retailing, 77, 435-56.

Heskett, J. L., Jones, T. O., Loveman, G. W., Sasser, W. E., and Schlesinger, L. A. (1994), "Putting the ServiceProfit Chain to Work." Harvard Business Review. 72(2), 164-170.

Howard J. A and Sheth, J. N. (1969), The Theory of Buyer Behavior, New York, John Wiley \& Sons.

Hoffman Donna. L. and Novak, Thomas P. (1996), "Marketing in Hypermedia Computer-Mediated Environments: Conceptual Foundations," Journal of Marketing, 60, 50-68.

Hunt, H. Keith (1977), "CS/D - Overview and Future Directions," in Conceptualization and Measurement of Consumer Satisfaction and Dissatisfaction, H. Keith Hunt, ed., Cambridge, Mass.: Marketing Science Institute.

Jawward, R., Dorota, B., Keith, G., Mehmet, C., and Veronica, M. (2013), “Achieving Customer Satisfaction through Integrated Products and Services: An Exploratory Study," Journal of Product Innovation and Management, 30(6), 1128-1144.

Jones, Thomas O. and Sasser, W. Earl Jr. (1995), "Why satisfied Customers Defect," Harvard Business Review, 73 (November/December), 88-99. 
Jung, Kwon, Cho, Yoon C., and Lee, Sun (2014), “Online Shoppers' Response to Price Comparison Sites: Moderating Role of Product Type and Price Consciousness on Price and Value Perceptions," Journal of Business Research, 67(10), October, 2079-2087.

Kaur, Harsandaldeep and Soch, Harmeen (2012), "Validating Antecedents of Customer Loyalty for Indian Cell Phone Users," The Journal of Decision Makers, 37(4), 47-61.

Keller, Kevin (1993), "Conceptualizing, Measuring, and Managing Customer Based Brand Equity," Journal of Marketing. 57 (January), 1-22.

Kotler, P. (1994), "Marketing Management: Analysis, Planning, Implementation, and Control," 8th ed., New Jersey, Prentice Hall, Inc.

Lee, Jonathan, Lee, Janghyuk, and Feick, Lawrence (2001), "The Impact of Switching Costs on the Customer Satisfaction-Loyalty Link: Mobile Phone Service in France," Journal of Services Marketing, 15(1), 35-48.

Lee, Seongil (2009), “Mobile Internet Services from Consumers' Perspectives," Intl. Journal of Human-Computer Interaction, 25(5), 390-413.

Lee, Sungkyu, Lee, Jong-ho, and Garrett, Tony C. (2013), "A Study of the Attitude toward Convergent Products: A Focus on the Consumer Perception of Functionalities," Journal of Product Innovation Management, 30(1), 123-135.

Liu, C. C. (2010), "Measuring and Prioritizing Value of Mobile Phone Usage," International Journal of Mobile Communications, 8(1), 41-52.

Lamelas, Maria del Carmen Lopez (2011), "Conceptualizing and Measuring the Influence of Corporate Image on Country of Origin Image: the Case of Spain,” Brunel Business School Brunel University.

Marshall, A. (1920), Principles of Economics, 8th ed., London: Macmillan.

Martin, I. M. \& Eroglu, S. (1993), "Measuring a Multi-Dimensional Construct: Country Image," Journal of Business Research. 28(3), 191-210.

Mittal, B. and Lassar, W. M. (1998), "Why Do Customers Switch? The Dynamics of Satisfaction versus Loyalty," The Journal of Services Marketing, 12(3), 177-94.

Moffitt, M. A. (1994), "A Cultural Studies Perspective toward Understanding Corporate Images: A Case Study of State Farm Insurance," Journal of Public Relations Research, 6(1), 41-66.

Nagashima, Akira. (1970), “A Comparison of Japanese and U.S. Attitudes Toward Foreign Products," Journal of Marketing. 34(1), January, 68-74.

Obermiller, Carl and Spangenberg, Eric (1989), "Exploring the Effects of Country-of-Origin Labels: An Information Processing Framework," Advertising Consumer Research. 16(1), 454-59.

Oliver, Richard L. (1997), Satisfaction: A Behavioral Perspective on the Consumer, McGraw-Hill Company, Inc., New York, NY.

Oliver, Richard L. (1980), "A Cognitive Model of the Antecedents and Consequences of Satisfaction Decisions," Journal of Marketing Research, 17, (November), 460-469.

Oliver, Richard L. (1981), "Measurement and Evaluation of Satisfaction Processes in Retail Settings," Journal of Retailing, 57 (Fall), 25-48.

Oliver, Richard L. (1999), “Whence Consumer Loyalty,” Journal of Marketing. 63(4), 33-44.

Olshavsky, Richard W., and John A. Miller (1972), "Consumer Expectation, Product Performance, and Perceived Product Quality," Journal of Marketing Research, 9 (February), 19-21.

Parasuraman, A., Leonard L. Berry, and Valarie A. Zeithaml. (1991), "Understanding Customer Expectations of Service," Sloan Management Review. 32(3), 39-48.

Peter, N. G., Mitra, D. and Moorman, C. (2012), "What is Quality? An Integrative Framework of Processes and States," Journal of Marketing, 76, July, 1-23.

Reichheld, F. F. (1994), "Loyalty and the Renaissance of Marketing," Marketing Management. 2(4), 10-21.

Reigrotski E. and Anderson N. (1986), "National Stereotypes and Foreign Contacts," The Public Opinion Quarterly, 23(4), 5151-528.

Rijsdijk, Serge A. and Hultink, Erik Jan (2009), "How Today's Consumers Perceive Tomorrow's Smart Products," Journal of Product Innovation Management, 26, 24-42.

Roth, M. S. \& Romeo, J. B. (1992), "Matching Product Category and Country Image Perceptions: A Framework for Managing Country-of-Origin Effects," Journal of International Business Studies. 23(3), 477-498.

Rust, Roland T., Zahorik, Anthony J., and Keiningham, Timothy L. (1995), "Return on Quality (ROQ): Making Service Quality Financially Accountable," Journal of Marketing. 59 (April), 58-70. 
Sagynov, Esen and Cho, Yoon C. (2015), "Exploring Factors That Affect Usefulness, Ease Of Use, Trust, And Purchase Intention In The Online Environment," International Journal of Management \& Information Systems, 19(1), 21-35.

Sakthivalrani, S. and Kannan, S. (2013), "Customer Satisfaction and Behavioral Intention towards Mobile Network Service Providers," Asia Pacific Journal of Research in Business Management, 4(4).

Schooler, R. D. (1965), "Product bias in the Central American Common Market," Journal of Marketing Research, 2(4), 394-397.

Scott, W. A. (1966), Psychological and Social Correlates of International Image, In H. C. Kelman (ed), International Behavior, New York: Halt, Reinhart \& Winston.

Sherif, Muzafer and Hovland, Carl I. (1961), Social Judgment: Assimilation and Contrast Effects in Communication and Attitude Change, New Haven, Conn.: Yale University Press.

Sheth, J. N. (1973), "Model of Industrial Buyer Behavior.” Journal of Marketing, 37, 50-56.

Sivadass, E. and Baker-Prewitt, J. L. (2000), "An Examination of the Relationship between Service Quality, Customer Satisfaction and Store Loyalty," International Journal of retail and Distribution management. 28 (2), 73-82.

Srivastava, Kavita and Sharma, Narendra K. (2013), "Service Quality, Corporate Brand Image, and Switching Behavior: The Mediating Role of Customer Satisfaction and Repurchase Intention," Services Marketing Quarterly, 34, 274-291.

Tsai, Kuang-Hsun and Yeh, Kun-huang (2012), “The Impact of Experiential Marketing and Qualia on the Brand Image, Customer Satisfaction and Loyalty: With the Digital Camera as an Example," Marketing Review, 9(2), 161-180.

Tse, David K. and Peter C. Wilton (1988), "Models of Consumer Satisfaction Formation: An Extension,” Journal of Marketing Research. 25 (May), 204-12.

Westbrook, R. A. (1980), "Interpersonal Affective Influences on Consumer Satisfaction with Product," Journal of Consumer Research. 9, 148-163.

Westbrook R. A. And Michael D. Reilly (1983), "Value-Percept Disparity: An Alternative to the Disconfirmation of Expectations Theory of Consumer Satisfaction," Advances in Consumer Research, 10, 256-261.

Wong, Winnie Poh-Ming, Lo, May-Chiun, and Ramayah, T. (2014), "The Effects of Technology Acceptance factors on Customer E-Loyalty and E-Satisfaction in Malaysia," International Journal of Business and Society, 15(3), 477-502.

Woodside, Arch G. (1972), "Positive Disconfirmation of Expectation and the Effect of Effort on Evaluation," Proceedings, 80th Annual Convention of the American Psychological Association, 743-744.

Yi, Youjae (1990), “A Critical Review of Consumer Satisfaction,” In Valarie A. Zeithaml (ed.), Review of Marketing, American Marketing Association, Chicago, 68-123.

Zeithaml, A.V. (1988), "Consumer Perceptions of Price, Quality, and Value: A Means-end Model and Synthesis of Evidence," Journal of Marketing, 52(7), 2-22.

Zheng Fang, Xueming Luo, and Minhua Jiang (2013), "Quantifying the Dynamic Effects of Service Recovery on Customer satisfaction: Evidence from Chinese Mobile Phone Markets,” Journal Service Research, 16(3), 341-355.

\section{ONLINE RESOURCES}

http://www.icsid.org (International Council of Societies of Industrial Design) 


\section{NOTES}

